\title{
Thinking Through the Pandemic: A Symposium
}

Source: Science Fiction Studies, November 2020, Vol. 47, No. 3 (November 2020), pp. 321-376

Published by: SF-TH Inc

Stable URL: https://www.jstor.org/stable/10.5621/scief ictstud.47.3.0321

JSTOR is a not-for-profit service that helps scholars, researchers, and students discover, use, and build upon a wide range of content in a trusted digital archive. We use information technology and tools to increase productivity and facilitate new forms of scholarship. For more information about JSTOR, please contact support@jstor.org.

Your use of the JSTOR archive indicates your acceptance of the Terms \& Conditions of Use, available at https://about.jstor.org/terms 
the novel's protagonists, to be captivated by the future is to move painfully through the present, "as though through mud." In play, movement through space and time is less onerous but not without consequences. Play simply asks us to luxuriate in the mud.-Alenda Y. Chang, University of California, Santa Barbara

The Pandemic that was Always Here, and Afterward: From Futures to CoFutures. By now, we all know that the inequalities brought to light by the coronavirus, the so-called equal opportunity killer, existed long before the pandemic. The disproportionate toll it continues to take on the disadvantaged and the elderly has already generated plenty of wet dreams about societal eugenics. That COVID-19 does not affect children much is an added advantage, because it ensures a steady supply of wage-slave labor within the necropolitical space of capitalist globalization-and also, perversely, because it deprioritizes the burden of care that children inspire. After all, the image of the sick/abused child gives potency to the image of societal sickness. Ursula K. Le Guin's "The Ones who Walk Away from Omelas" (1973), for example, is superficially about a foodtaster, an expendable inconvenience to keep the body politic healthy. At a deeper level, the fantasy is that of the epidemic-localized disease-affected bodies-that keep the transnational capitalist system functioning with the illusory veneer of utopia. Whether the utopia is located in the global north, away from the expendable diseased or dysfunctional global south, is immaterial. The fractures internal to societies everywhere mirror and bolster the system.

In her counternarrative challenge to Le Guin's classic story, "The Ones Who Stay and Fight" (2018), N.K. Jemisin speaks instead to the burden of confronting injustices perpetrated in the name of purity and cleanliness worldwide, where health is maintained in one space at the cost of debility in others. Pandemics are the painful poster child of globalization. The pandemic shows that while some might see the "normalcy" of injustices as unsustainable if the inhabitants (including nonhumans) of this planet are to survive, it is precisely the unsustainability that for others has the chaotic potential to further cleave and destroy democratic societies, exacerbate exclusionary politics, and rebirth fascisms with genocidal intent. The values of "life" and/versus the "economy" are the rhetorical battleground of this unsustainability. Those who will deploy the pandemic as a means of control will try to ensure that while the movement of people, locally, nationally, or internationally, is brought under even greater regulation, creating wider physical distance with social distance, the flow of goods and consumption will remain undisturbed to maintain necroeconomics. This is the rehashed logic of colonialism underlying the normalcy of neocolonialism. Indeed, the pandemic has always been here, revealing its murderous grin in the passage of numbers, statistics, and the taxation of one's life-value as a non-performing unit in death tolls.

Sf has shown that these patterns have a precedent, and also a future potentiality. Epidemics, pandemics, and catastrophes in general are staples, especially in post-apocalyptic narratives of collapses and resurrections. 
Lockdowns, surveillance states, ghettoization are quite prominent themes in banal dystopias susceptible to managerial techniques. But we have also seen these wastelands of disaster set in global-south narratives or in sf by marginalized communities where catastrophe is just Tuesday. Whether laced with hope or not, the fight in and against the wasteland in these other narratives makes the condition of permanent catastrophe appear historical, not for catharsis, but possible strategy. For example, Cherie Dimaline's The Marrow Thieves (2017) describes a pandemic that has always been with the indigenous people: a future predicated on differentially paced destruction of indigenous futures. Dreams built on top of stolen dreams. Or take the words of the father telling his son in Alex Rivera's film Sleep Dealer (2009) that the future was stolen from Mexico when it was turned into a corporatized dystopia. How can one use the science-fictional imagination as a way to think past the dystopic to futures with an ever-increasing emphasis on equity and equality? Does the pandemic offer us ways to transform our politics, at both systemic and personal levels?

What science-fictional thinking can offer us at a time like this is the chance to rebuild the narrative of solidarities for possible futures, seizing control from the closed futures of disaster capitalism. At our moment in history, closed futures have an irresistible gravity. A permanent state of crisis closes off the future in its potentiality and makes history appear cyclical: the developed parts of the world and all their infrastructure seem to be collapsing and their oil regimes coming to an end, which makes the poorer parts of the world-with their supposed poverty, failed or undemocratic governments, and smothered cultures, long kept trapped in the rhetoric of backwardness or belated modernities-now suddenly appear futuristic. Yet sf narratives, especially from marginalized communities for whom the dystopian is an everyday reality, have developed futures without the need for cyclicality, offering visions of alternative futures instead in their many alternative futurisms, whether Afro or Africanfuturisms or Indigenous futurisms or Latinxfuturisms or any such movements around the world. Mythic cyclicality closes off the future, while history opens the future by being sensitive to possibility. The quests for these futurisms have been to find antidotes to dystopia, sometimes through their own history and sometimes through imaginaries of the future, to find moments of solidarity in the chaos of the everyday, and to find meaning in survival within cultures of protest and resistance. Or, as Nnedi Okorafor says it: From Broken Places to Outer Spaces (2019).

What is needed next is a further move: solidarity across futurisms without devolution into comparative or ethnofuturisms (for that will return us to the fractures of our pasts and presents). I have termed this move cofutures: complex, coeval, and most importantly, compossible. Compossibility requires solidarity despite, and often because of, a recognition of difference. Things are not completely smooth and never will be, but we will get through this together to build just futures for all if we can work together as a people. But how do we do it? One face of the pandemic is grief over the loss of both lives and 
livelihoods, compounded by violence and uncertainty, revealing fractures in global systems that rely on greater atomization of labor, tremulously fragile supply-chain webs, and the precarity of life. The other face of the pandemic has been solidarity-building across peoples and communities. The globalization of care-work comes with the recognition of transnational connectivities of the disaster from which no one is protected. A template has been made. What is needed for our cofutures is a theory of compossible futures based on solidarities. This theory will require us to jump back and forth among the positive futures we want, the present we have been given, and the futures we are making in our everyday lives. And science-fictional worldbuilding based on possibility can exhibit such compossibility. Thinking in terms of compossibility-thinking compossible futures-will require practice, for only then can cofutures become possible. I keep my hope.-Bodhisattva Chattopadhyay, University of Oslo

Learning from Lauren. When the viral pandemic hit, the devastation was weirdly familiar. I found myself thinking like Lauren in Octavia Butler's Parable of the Sower (1993) and Parable of the Talents (1998): should I pack an emergency backpack? What seeds should I be collecting and storing? Annotating J.G. Ballard's 1960s ecocatastrophe fictions and John Wyndham's "cosy catastrophes" for my summer term teaching on the Anthropocene, I was similarly eking out an unexpectedly apocalyptic existence-struggling to source food and living in a decelerated temporality of lockdown confinement. It was somewhere between Mitchell and Webb's apocalyptic gameshow "Remain Indoors" (first broadcast in their comedy sketch show in 2006) and Bill and Josella's Sussex pastoral enclave in John Wyndham's Day of the Triffids (1951), with hints of the narrator's phantasmagoric journeys beyond the wall of her flat in Doris Lessing's Memoirs of a Survivor (1974).

For me, ecocatastrophe narratives contain odd moments of pleasure amid the societal wreckage in utopian glimpses of a world beyond capitalist productivity. This combination of disaster and possibility - what Rebecca Solnit calls "disaster utopias" (21) in A Paradise Built in Hell (Penguin 2009), drawing on Michael Barkun's 1974 Disaster and the Millennium (Syracuse UP 1974, 7) - was evident in the crisis unleashed by the novel Coronavirus. Since COVID-19 was named a global pandemic, explicit utopian political demands that were previously unthinkable have become thinkable-calls for the reduction of the length of the working day and the working week, which date back to socialist agitation in the mid-nineteenth century, or the implementation of Universal Basic Income (UBI). Such demands would finally enact the late nineteenth-century dream of utopian socialist tales of a world beyond scarcity, as seen in the pneumatic mechanization of Edward Bellamy's Looking Backward (1888) or the automated chemical production of food in Mary E. Bradley Lane's eugenicist feminist text, Mizora: A World of Women (1890). Such narratives liberated the downtrodden working subject into leisure and imagined how we might spend our newly found free time in creative pursuits such as painting, dancing, cooking, and cultivating aesthetic taste. This older utopian imaginary was similarly echoed in the best 